\title{
THE EFFECT OF NANO-CHEMICAL ON THE SHEAR STRENGTH PROPERTIES OF SOILS
}

\author{
Akolade, A.S ${ }^{1}$, Oyekanmi, O. A ${ }^{2}$, Aleshinloye, A. O ${ }^{3}$, Alabi, O.T ${ }^{4}$ \\ ${ }^{1}$ Department of Civil Engineering, Lead City University, Ibadan, Nigeria. \\ ${ }^{2}$ Works and Services Department, The Polytechnic Iree, Osun, Nigeria. \\ ${ }^{3}$ Department of Civil Engineering, University of Ibadan, Ibadan Nigeria. \\ ${ }^{4}$ Department of Civil Engineering, The Polytechnic, Ibadan, Ibadan, Nigeria
}

\begin{abstract}
Lateritic soils are used as a road making material and they form the sub-grade of most tropical road. For the durability of the soil material which is to be used as subgrade, there is need to improve it mechanical properties by some suitable means mostly soil stabilization.
\end{abstract}

This research studied the effect of terrasil on the geotechnical properties of subgrade material which was subjected to shear strength test. Four soil samples were collected from Eleyele area of Ido local government and labeled (A, B, C and D) at random. These samples were taken to the Laboratory for experiments to identify and determine the Grain size analysis, Atterberg, compaction and shear strength parameters at different dosages of Terrasil of $0 \%, 10 \%, 20 \%$ and $30 \%$ under the curing period of 24 hours at the laboratory, sample A,B,C \& D shear strength values at $0 \%$ were $(17.7 \mathrm{KN} / \mathrm{m}, 18.55 \mathrm{KN} / \mathrm{m}, 14.17$ $\mathrm{KN} / \mathrm{m} \& 20.74 \mathrm{KN} / \mathrm{m})$ respectively, it was observed that the values at $10 \%$ were $(14.03$ $\mathrm{KN} / \mathrm{m}, 15.09 \mathrm{KN} / \mathrm{m}, 15.19 \mathrm{KN} / \mathrm{m} \& 10.84 \mathrm{KN} / \mathrm{m})$ and the values at $20 \%$ were $(8.54 \mathrm{KN} / \mathrm{m}, 9.85$ $\mathrm{KN} / \mathrm{m}, 8.84 \mathrm{KN} / \mathrm{m} \& 7.21 \mathrm{KN} / \mathrm{m}$ ) while the values at $30 \%$ were $(6.75 \mathrm{KN} / \mathrm{m}, 7.80 \mathrm{KN} / \mathrm{m}, 8.43 \mathrm{KN} / \mathrm{m}$ and $7.74 \mathrm{KN} / \mathrm{m})$. This result indicates that the more the additive the less the shear strength value.

The differences in the behavior of the soil under the influence of terrasil at the curing period of 24 hours shows that there is need to find out the influence of terrasil on the properties of the soil under a longer duration of about a year.

Keywords; Subgrade, Stabilization, Terrasil, Shear strength.

\section{INTRODUCTION}

Transportation by road is the most important facility in moving men and material. It contributes to the economic, industrial, social and cultural development of a region or state of nation. It helps primarily in linking production and consumption centers (Damodariya \& Parmar, 2016).

In this tropical part of the world, lateritic soils are used as a road making material and they form the sub-grade of most tropical road. They are used as sub base and bases for low cost roads and these carry low to medium traffic (Quadri \& Olafusi, 2012). In the construction of pavements, laterite is widely used as subgrade which serves as foundation for the pavement (Akolade \& Olaniyan 2014), lateritic soils classified as A-3, A-2-4 and A-2-6 are adjudged suitable for sub-grade, good fill, sub-base and base materials (Amadi, \& Francis, 2015)

The means of improving the soil properties is known as soil stabilization, the major forms of conventional soil stabilization are chemical and mechanical stabilization techniques; such as application of heat, lime/cement, polymer resins, geogrids, geotextile, geonet e.t.c.

New solutions are to be developed that gives all-season, pavement resistance, ensuring faster transportation and minimizing the risk of accidents. Nanotechnology is one such reformed mode which when potentially can redefine and address the rising concern of poor quality roads. Transitioning to the nano scale implies an enormous increase of the surface area with respect to the volume. Nanoparticles interact very actively with other particles and solutions such that very minute amounts may lead to considerable effects on the physicochemical behaviour and engineering properties of soil. This research investigates into the nanoparticle known as the terrasil. Terrasil chemical is emerging as a new material for the stabilization of soil. Terrasil is nanotechnology based 100 percent organosilane, water soluble, ultraviolet and heat stable, reactive soil modifier to waterproof soil subgrade (Johnson \& Rangaswamy, 2015). It reacts with water loving 


\section{International Journal of Engineering Applied Sciences and Technology, 2020 \\ Vol. 5, Issue 1, ISSN No. 2455-2143, Pages 757-762 \\ Published Online May 2020 in IJEAST (http://www.ijeast.com)}

silanol groups of sand, silt, clay and aggregates to convert it to highly stable water repellent alkyl Siloxane bonds and forms a breathable in-situ membrane. It resolves the critical sub-surface issues. It is water soluble, chemically reactive and nonleachable and works well with all silicate containing materials, it can be applied to almost all types of soil. Nanochemicals can be identified as environmental friendly since they conserve limiting resources like aggregates and bitumen (Johnson \& Rangaswamy, 2015).

\section{MATERIALS AND METHOD}

In this research work, laboratory analyses were conducted to achieve the objectives. Four samples of soil were collected from a borrow pit at different points and were identified as A, B, C, and D of $20 \mathrm{~m}$ distances apart along a river bank, with coordinate (Lat 7.418305 Long 3.868283, Lat
7.419462 Long 3.867137, Lat 7.41927 Long 3.867337 and Lat 7.419227 Long 3.867347) respectively. The following test; atterberg limit test, sieve analysis, compaction test and tri-axial text were carried out on the samples. Atterberg test was done to determine the plastic limit, liquid limits, and plastic index of the soil samples, while sieve analysis was done to determine the particle sizes that were contained in the samples, compaction test was carried out to determine the OMC and MDD of the samples by packing together of the soil particles and tri-axial to determine the shear strength parameters. Proctor compaction tests were conducted which involves the use of 4-inches-diameter mould with the compaction of three layers of soil using 27 blows by a $5.51 \mathrm{~b}$. Hammer falling 12 inches. Finally tri-axial test was conducted to determine the sample shear strength parameters with and without terrasil under 24 hours period and the engineering properties were observed.

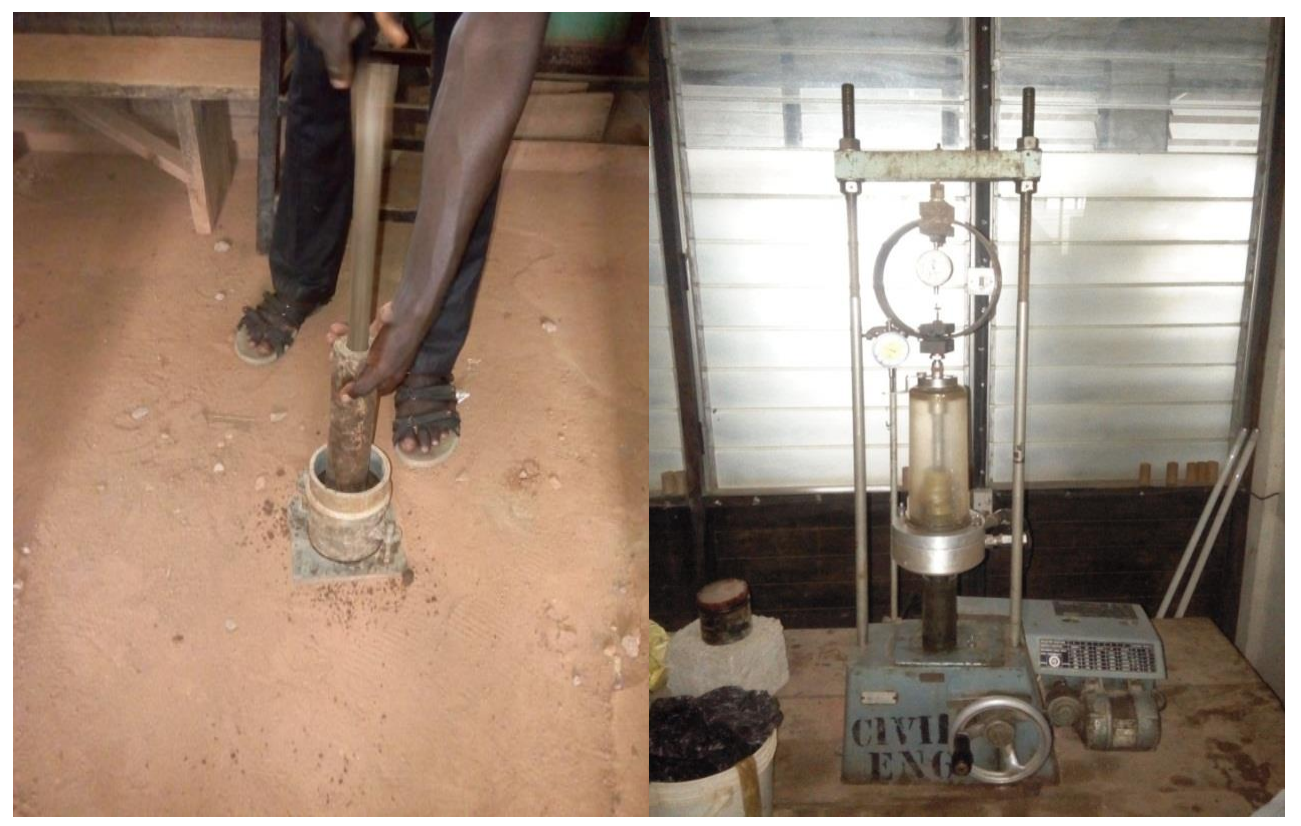

Fig 1: Experimental operation (Compaction and Tri-axial Test)

\section{RESULT AND DISCUSSION}

The summary of the result of the laboratory test (grain size analysis, compaction and atterbergs limit) shown below. The engineering property test (triaxial) is presented in the tables and figures below.

\section{a. Sieve Analysis}

According to clause 6201 of Federal Ministry of Works and Housing (F.M.W \& H)
Specification Requirement, for a sample to be used as both subgrade/fill and base, the percentage by weight passing the No.200 sieve $(75 \mu \mathrm{m})$ shall be less than but not greater than $35 \%$. And if the percentage passing sieve No. 200 for a Lateritic base course is greater than $35 \%$, no need for further tests and material rejected. (Habeeb \& Quadri, 2012).

Grain size analysis or gradation test was a procedure used in the experiment to assess the 
particle size distribution of preliminary sample A, B, $\mathrm{C}$ and $\mathrm{D}$ of a granular material. These were shown in the tables and figures below. The percentage passing through No. 200(75 micron) sieve from the four samples ranges between $7.73 \%$ and $15.83 \%$ which indicates that the samples are coarse.

Table 1 Sieve Analysis of preliminary Results for sample A

\begin{tabular}{llll}
\hline Sieve size & Weight retained in gms & Percentage retained & Total \% passing \\
\hline $\mathbf{2 . 3 6} \mathbf{m m}$ & 39.00 & 13.43 & 86.57 \\
$\mathbf{4 2 5}$ micron & 36.00 & 12.40 & 45.05 \\
$\mathbf{7 5 m i c r o n}$ & 44.40 & 15.30 & 14.86 \\
\hline
\end{tabular}

Table 2 Sieve Analysis of preliminary Results for Sample B

\begin{tabular}{llll}
\hline Sieve size & Weight retained in gms & Percentage retained & Total \% passing \\
\hline $\mathbf{2 . 3 6} \mathbf{m m}$ & 30.50 & 12.71 & 87.29 \\
$\mathbf{4 2 5}$ micron & 29.50 & 12.29 & 47.31 \\
$\mathbf{7 5 m i c r o n}$ & 38.50 & 16.04 & 15.83 \\
\hline
\end{tabular}

Table 3 Sieve Analysis of preliminary Results for Sample C

\begin{tabular}{llll}
\hline Sieve size & Weight retained in gms & Percentage retained & Total \% passing \\
\hline $\mathbf{2 . 3 6} \mathbf{m m}$ & 60.50 & 18.06 & 81.94 \\
$\mathbf{4 2 5}$ micron & 42.50 & 12.69 & 41.16 \\
75micron & 61.61 & 18.38 & 8.15 \\
\hline
\end{tabular}

Table 4 Sieve Analysis of preliminary Results for Sample D

\begin{tabular}{llll}
\hline Sieve size & Weight retained in gms & Percentage retained & Total \% passing \\
\hline 2.36 mm & 52.50 & 17.36 & 82.62 \\
425micron & 44.00 & 14.54 & 37.56 \\
75micron & 32.00 & 10.58 & 7.73 \\
\hline
\end{tabular}

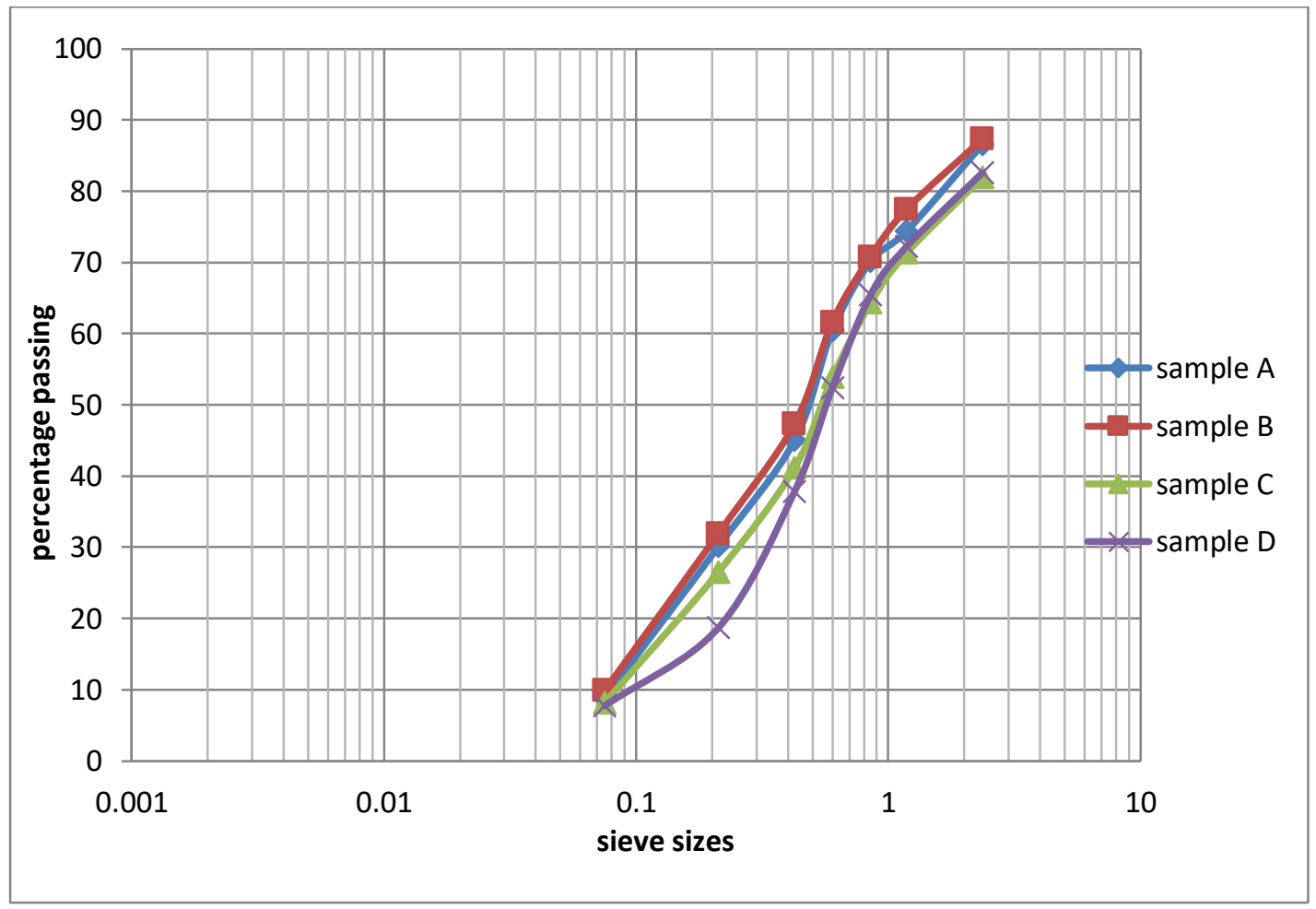

Fig 2: Graph of particle size analysis 


\section{b. Atterberg Limit Test}

Atterberg limit test was performed to determine the soil liquid limit, plastic limit and plastic index. According to Federal Ministry of Works and Housing (F.M.W \& H) Specification Requirement in clauses 6201 and 6252 , material passing the $425 \mu \mathrm{m}$ sieve shall have a liquid limit of not more than $35 \%$ and a
Plastic Index (P.I) of not more than $12 \%$ as determined by American Society for Testing Materials Method (Habeeb \& Quadri, 2012). Sample A, B, C, D fall within the category of low plasticity since there plasticity index did not exceed $35 \%$ (UNESCO, 2008)

Table 5 Atterberg limit results

\begin{tabular}{|c|c|c|c|c|}
\hline & Sample A & Sample B & Sample C & Sample D \\
\hline \multicolumn{5}{|l|}{ Consistency limits (\%) } \\
\hline a) Liquid limit & 25.20 & 25.00 & 22.50 & 22.50 \\
\hline b) Plastic limit & 15.50 & 15.39 & 10.98 & 12.73 \\
\hline c)Plasticity index & $9.7 \%$ & $9.61 \%$ & $11.52 \%$ & $9.77 \%$ \\
\hline $\begin{array}{l}\text { c. } \\
\text { The compaction } \\
\text { to obtain the optimum } \\
\text { the (MDD) of soil samp }\end{array}$ & $\begin{array}{l}\text { ion Test } \\
\text { as carried out in order } \\
\text { e content (OMC) and } \\
\text { le } 6 \text { below shows the }\end{array}$ & $\begin{array}{l}\text { corresp } \\
\text { content } \\
\text { OMC } \\
\text { curve } \\
\text { strengtl }\end{array}$ & $\begin{array}{l}\text { Irves of dry } \\
\text { ples were d } \\
\text { btained fror } \\
\text { to prepare }\end{array}$ & $\begin{array}{l}\text { against moisture } \\
\text { in Fig 2. The } \\
\text { moisture-density } \\
\text { mples for shear }\end{array}$ \\
\hline
\end{tabular}

compaction test result for the soil samples while the

Table 6 Geotechnical \& engineering properties of samples

\begin{tabular}{lllll}
\hline & Sample A & Sample B & Sample C & Sample D \\
\hline $\begin{array}{l}\text { Soil classification } \\
\text { Engineering properties }\end{array}$ & A-2-4 & A-2-4 & A-2-6 & A-2-4 \\
a) M.D.D & 1.94 & 1.89 & & \\
b) O.M.C & $11.42 \%$ & $10.50 \%$ & 1.97 & 1.97 \\
\hline
\end{tabular}

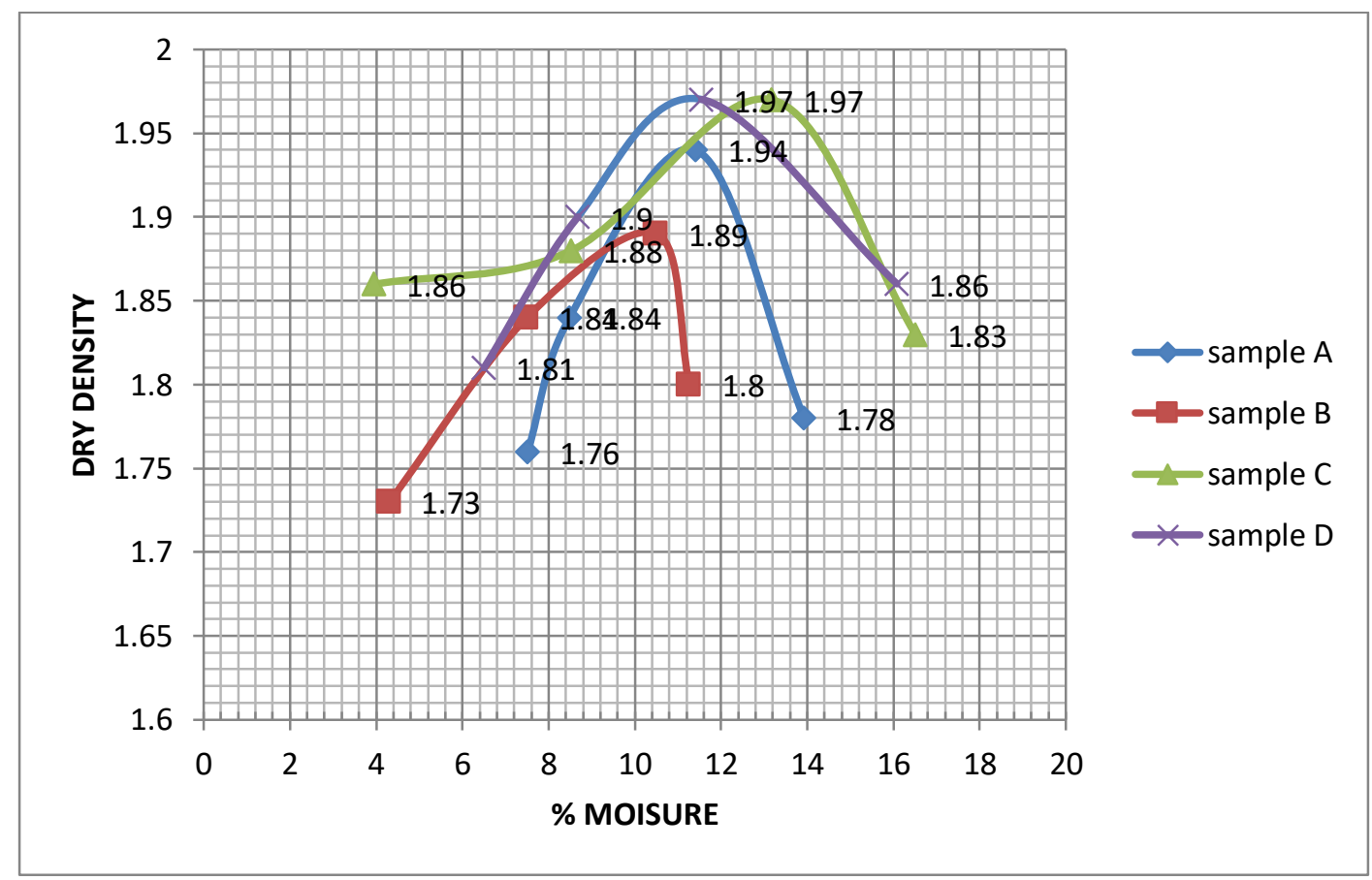

Fig 3 Graph of dry density against \% moisture 


\subsection{Tri-axial Test}

Tri-axial tests were conducted under the curing period of 24 hours with varying percentages of terrasil. The results are tabulated in table below. The experiment shows that with increase in dosage, there were regressions in shear strength parameters.

Table 7 shear strength results for all the soil samples

\begin{tabular}{lllll}
\hline & Dosage (\%) & $\begin{array}{l}\text { Cohension } \\
\text { C }\end{array}$ & $\begin{array}{l}\text { Angle of friction } \\
\boldsymbol{\emptyset}\end{array}$ & $\begin{array}{l}\text { Shear strength } \\
(\mathbf{K N} / \mathbf{m})\end{array}$ \\
\hline Sample 1 & 0 & 5 & 11 & 17.7 \\
& 10 & 10 & 4 & 14.03 \\
& 20 & 3 & 6 & 8.54 \\
Sample 2 & 30 & 4 & 3 & 6.75 \\
& 0 & 5 & 11 & 18.55 \\
& 10 & 6 & 2 & 15.09 \\
& 20 & 5 & 4 & 9.85 \\
Sample 3 & 30 & 9 & 3 & 7.80 \\
& 0 & 11 & 4 & 14.17 \\
& 10 & 5 & 4 & 15.19 \\
Sample 4 & 20 & 5 & 4 & 8.84 \\
& 30 & 4 & 3 & 8.43 \\
& 0 & 10 & 14 & 20.74 \\
& 10 & 5 & 5 & 10.87 \\
& 20 & 4 & 3 & 7.21 \\
\hline
\end{tabular}

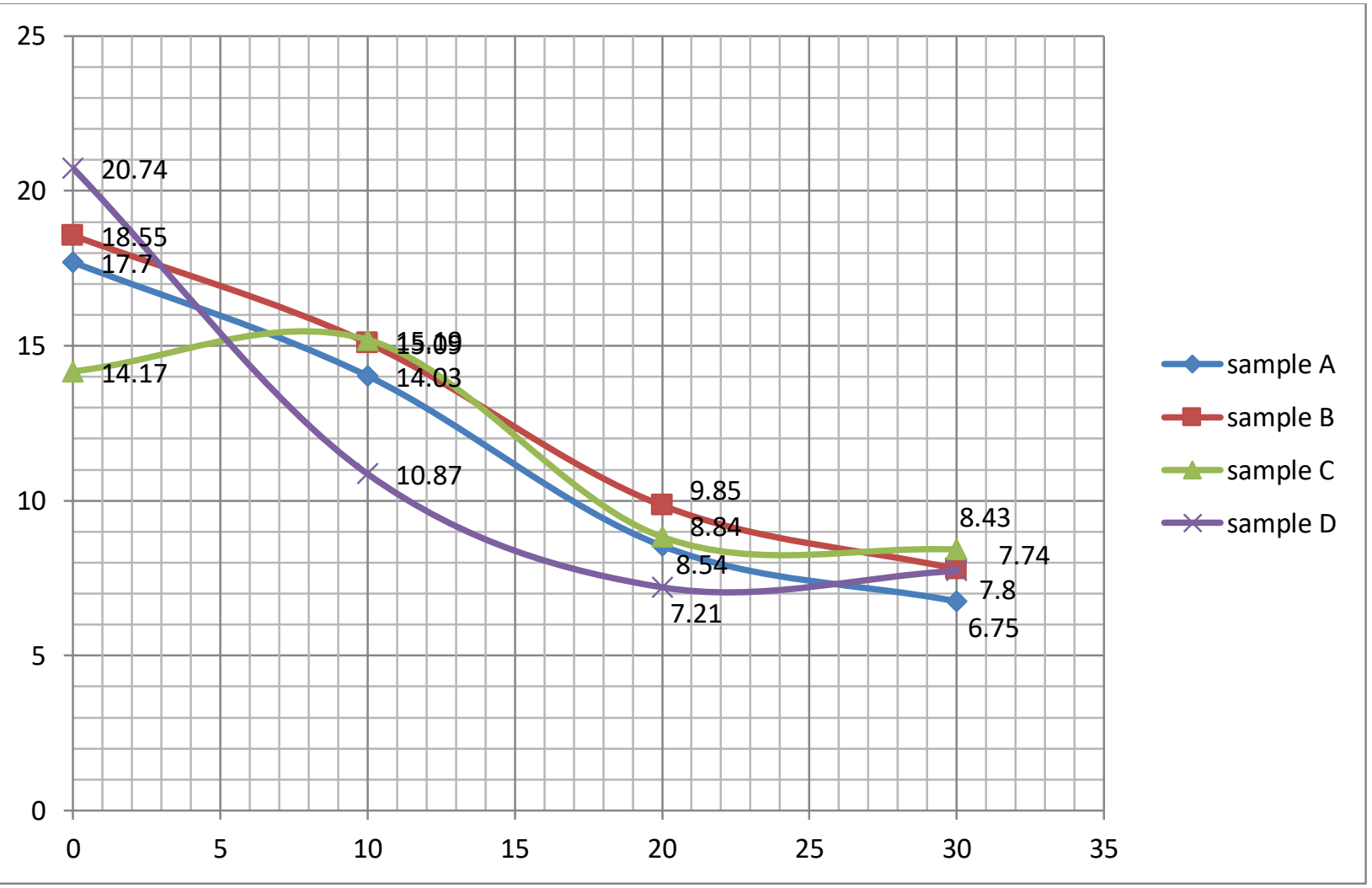

Figure 4 shows the regression of shear strength value against Percentage of terrasil dosage 


\section{International Journal of Engineering Applied Sciences and Technology, 2020 Vol. 5, Issue 1, ISSN No. 2455-2143, Pages 757-762 \\ Published Online May 2020 in IJEAST (http://www.ijeast.com)}

\section{CONCLUSION AND RECOMMENDATION}

The study investigated the effect of terrasil on the geotechnical properties of subgrade material under the curing period of 24 hours. Presence of terrasil in the four samples led to the reduction in the soil geotechnical properties such as cohesion, angle of friction, and shear strength values. However, the curing duration determines the effectiveness of terrasil on subgrade materials.

It is recommended that laboratory tests should be carried out on borrow pit materials to be used for construction so as to know their suitability for the intending purposes.

There is also a need to find out the influence of terrasil on the properties of the soil under a longer duration of about one year.

\section{REFERENCE}

1 Akolade, A.S and Olaniyan, O. S. (2014).Application of Geogrids on the Geotechnical Properties of Subgrade Materials under Soaked Condition Civil and Environmental Research www.iiste.org ISSN 2224-5790 (Paper) ISSN 2225-0514 (Online) Vol.6, No.7, 2014. pp. $12-19$.

2 Amadi A.N., Akande W. G., Okunlola I. A., Jimoh M.O., and Francis Deborah G.,(2015) "Assessment of the Geotechnical Properties of Lateritic Soils in Minna, North Central Nigeria for Road design and Construction." American Journal of Mining and Metallurgy, vol. 3, no. 1 (2015): 15-20. doi: 10.12691/ajmm-3-1-3.

3 Ayininuola, G. M, Agbede, O. A and Franklin, S.O (2009): influence of calcium sulphate on sub-soil cohesion and angle of friction. Journal of applied sciences research. Vol. 5 No. 3,297-304.

4 B. M. Lekha, A. U Ravi Shanar and Gouthan Sarang (2012). Fatigue and Engineering Properties of Chemically Stabilized Soil for Pavements. Indian Geotechnical Journal, 43[1]:96-104.

5 Damodariya S.M, Mrudul U.V, Parmar N.B.(2016) Laboratory Investigation of Soil Stabilized using Terrasil IJSRD International Journal for Scientific Research \& Development | Vol. 4, Issue 03, 2016 | ISSN (online): 2321-0613.

6 Habeeb A. Quadri, Olabambo A. Adeyemi, Oladipupo S. Olafusi, (2012). Investigation of the Geotechnical Engineering Properties of Laterite as a Subgrade and Base Material for Road Constructions in Nigeria Civil and Environmental Research www.iiste.org ISSN 2222-1719(Paper) ISSN 2222-2863 (Online) Vol 2, No.8, 2012.

7 Odewumi, T.O, Alli, O. O and Akolade, A. $S$ (2018) "Effect of Terrasil on the Hydraulic Conductivity and Strength properties of Soil". Journal of New Trends, Nigerian Institute of Civil Engineers (NICE).

8 Rintu Johnson, Kodi Rangaswamy, (2015). Improvement of Soil Properties as a Road Base Material using Nano chemical Solution Indian Geotechnical Society (IGS) 50th Indian Geotechnical Conference 17th -19 th December 2015.

9 S.V, Neehu and S. Remya (2013). Engineering Behaviour Of Nanoclay Stabilized Soil.international journal of civil and environmental engineering 4(6).pp. 321-328.

10 Quadri,H. A and Olafusi,O.S (2012) Investigation of the Geotechnical Engineering Properties of Laterite as a Subgrade and Base Material for Road Constructions in Nigeria. International Institute of Science, Technology and Education. Vol. 2, No 8 pp. 17 - 24.

11 UNESCO, Introduction of soil mechanics, version 1, December 2008 